\title{
Paradigma-verandering, relativisme en rasionaliteit
}

\author{
A J Antonites \\ Universiteit van Pretoria
}

\begin{abstract}
Paradigm-change, relativism and rationality

The impact of Kuhn's account of science is profound. This is also evident in the theological sciences. This could be seen by the importance given to problems like epistemological relativism, rationality and paradigmchange. The purpose of this paper is to give attention to these problems with reference to the HSRC Studies in Research Methodology's publication: Paradigms and progress in theology. It is edited by $\mathrm{J}$ Mouton, $\mathrm{A} \mathrm{G}$ van Aarde and W S Vorster.
\end{abstract}

\section{INLEIDING}

Die bedoeling van hierdie artikel is om andag te gee aan aspekte in die 1988RGN-navorsingsmetodologie-publikasie wat uitgegee is onder redaksie van J Mouton, A G van Aarde en W S Vorster. In hierdie publikasie gaan dit grootliks om die paradigma en wetenskaplike groei. Wanneer daar wetenskapsfilosofies van paradigma gepraat word, dan word dit wesenlik in 'n Kuhniaanse sin verstaan. Die impak van Kuhn op ander wetenskappe, en veral deur die wetenskapsfilosofie en metodologie, is nie net groot nie, maar die nawerking daarvan duur nog steeds voort - soos juis ook hierdie publikasie getuig. Die impak op die teologiese wetenskappe het nie uitgebly nie. Dit is merkwaardig dat sekere belangrike problematiek voortspruitend uit hierdie impak en wat by die ander wetenskappe na vore getree het, naamlik rasionaliteit, paradigma-verandering en relativisme, juis ook by die teologiese wetenskappe aan die orde gekom het - soos die voorafgaande simposium en publikasie ook getuig. 


\section{Paradigma-geladenheid van kennis}

Teoloë staan gekonfronteer met die vraag of daar in die hedendaagse tyd 'n paradigma-verandering besig is om plaas te vind en of 'n nuwe paradigma besig is om te verskyn. W S Vorster en A G van Aarde maak werk hiervan: Eersgenoemde meen dat dit op hande is terwyl laasgenoemde dit ontken. Albei aanvaar egter in beginsel die moontlikheid van paradigmas in die teologiese wetenskappe. In sy 'Towards a post-critical paradigm: Progress in New Testament scholarship?' stel Vorster dat die teologie onderweg is na 'n post-kritiese paradigma. Hiervolgens is onder andere die histories-kritiese paradigma aan die verdwyn. Vorster pas Kuhn deurgaans toe in sy hantering van die probleem: By die ou paradigma met sy normale wetenskap is daar 'n bepaalde wêreldbeeld, metodes, standaardoplossings, oplossingsprosedures, gemeenskaplike oortuigings ('beliefs'), dieselfde begrippe waarmee verklaar word. By die ou paradigma is die oorheersende manier van jou wêreld sien (in geval van die Nuwe-Testamentiese wetenskap is dit Nuwe-Testamentiese dokumente), histories. Deur McFague verwys Vorster na die Popperiaanse gedagte van die teorieafhanklikheid van feite - 'n siening wat Kuhn ook sou onderskryf.

Volgens Vorster se persepsie het daar nou inderdaad 'n paradigma-verskuiwing begin plaasvind. In terme van die teorie-afhanklikheid van die ou paradigma word 'feite', te wete tekste, gesien as betrokke by 'n groeiproses. Betekenis is geleë in die intensie van die outeur. Die teorie/paradigma lei die wetenskaplike om outentieke tekste vas te stel. Met 'n goeie argumentering wys Vorster daarop dat die fokus nou verskuif het. Dit impliseer natuurlik 'n nuwe teorie-afhanklikheid. Die paradigmaverskuiwing is vanaf die outeur van die teks na die teks as 'n outo-semantiese eenheid, ongeag die leser. $\mathrm{Na}$ die koms van onder andere moderne teksteorieë, narratologiese, retoriese en strukturalistiese teorieë word tekste as gehele gesien.

Die gedagte van 'sien' en 'fokus' is inderdaad hier belangrik. Kuhn slaag daarin om aan te toon dat teorieë veel meer is as blote teoretiese veralgemenings uit jou data. Inteendeel, daar is niks daarvan nie. Nog minder volg dit deduktief. Hoewel die data, feite, wêreld en objekte hoegenaamd nie onbelangrik word nie, is die grondgedagte van Kuhn dat hierdie gegewens nooit in enige wetenskap onafhanklik van 'n paradigma/teorie gesien kan word nie. Die paradigma is primêr 'n perspektief, 'n bepaalde manier van sien of fokus. Popper gebruik weer die uitdrukking 'soeklig'. Die paradigma sê dienooreenkomstig wat jy gaan sien en wat nie, wat relevant is en wat nie. 'No part of the aim of normal science is to call forth new sorts of phenomena; Indeed those that will not fit the box are often not seen at all' (Kuhn 1962:24). Die strukturalistiese teorie 'sien' geen betekenissse nie, aangesien sy fokus enigiets 'metafisies' as irrelevant beskou. Semantiese teorieë 'sien' weer betekenisse en wel as hoogs relevant. Betekenisse se epistemologiese status het 
derhalwe ingrypend verander.

'n Probleem hier is die logiese konsekwensies met betrekking tot die objekwêreld. Wetenskapsfilosowe soos Popper, Hanson, Kuhn en Toulmin het geargumenteer dat bruta facta, teorielose, volledig suiwere waarnemings, suiwere data, nie aangetoon kan word nie. Hanson sê (met sy bekende eend-haas gestalt) dat dit 'n geval is dat die wetenskaplike altyd iets sien 'as...' so en so (Hanson 1958:13). Kuhn meen weer dit is nooit 'n 'sien...as' nie, maar doodgewoon 'n 'sien' (Kuhn 1962:113). Hiermee word die positivistiese uiterste waar 'n mens nog steeds 'n Cartesiaanse dualisme kan veronderstel, ter syde gestel: Teorieë volg nie induktief as veralgemenings uit data nie. Wetenskaplike kennis is nie 'n blote registrasie van data en aldus kennis nie. By die logies-empiristiese of logies-positivistiese rekenskap van wetenskaplike kennis, is so 'n registrasie moontlik. Betekenis van terme is gebaseer op ervaring en data. Waarnemingskennis en terme se betekenis behels hiervolgens geen probleem nie, omdat waarnemingsuitsprake direk gekoppel is aan die wêreld en so na ervaring verwys. As daar enige ander faktor sou wees wat naas empiriese evidensie die aanvaarbaarheid van hipotesisse beïnvloed, dan moet sodanige faktore baie streng in formele vorm gegiet word. Waarnemingsuitsprake oor die wêreld is per se betekenisvol. Gevolglik is enige teorie wat geskei is of losgemaak is van waarneming, nie betekenisvol nie (Shapere 1981:38). Met 'n nuwe teorie/paradigma verkry die gegewene 'n nuwe interpretasie. Soortgelyke verwikkeling kan by nuwe teologiese teorieë aangetref word: Tekste is nie meer blote objekte nie, maar word gesien as synde teenwoordig in netwerk van relasies met ander tekste. Dit hou in dat betekenis skynbaar nie in 'n teks teenwoordig is nie, maar 'n teks het betekenis vanweë sy relasie met ander tekste. Dis dus 'n netwerk van intertekstualiteit (Vorster 1988:38).

Die vraag is nou of die teorie-afhanklikheid in hierdie situasie ook nie te ver gevoer kan word nie, sodat ons 'n ander moontlike uiterste kry: waar die een uiterste die objek-wêreld en empiriese kennis daaromtrent as laaste en onafhanklike arbiter stel, is die vraag of die teorie-afhanklikheid van kennis nie weer die betekenisvolheid van teorieë te onafhanklik van die wêreld kan stel nie. Sou mens dan kon sê dat enige uitspraak oor die wêreld slegs betekenisvol is vir soverre dit gekoppel is aan paradigmas/teorieë? Dit sou inhou dat die betekenis van ieder en elke wetenskaplike uitspraak volledig afhanklik is van sy teorie konteks. Sou die teorie net tot 'n mate verander, beteken dit dat die betekenis van elke term in die teorie moet verander? Daar is dus geen kern van byvoorbeeld waarnemingsuitsprake wat gemeenskaplik is aan alle gemeenskaplike paradigmas nie. Die vraag wat Shapere in so 'n geval vra is: Is daar geen kriterium of manier om te beslis wat gaan geld as 'n deel van die 'betekenis' van 'n term of wat gaan geld as 'n 
'verandering van betekenis' van 'n term nie (Shapere 1981:42)? Op watter punt gaan sulke veranderinge groot genoeg word om 'n verandering van teorie te konstitueer, sodat dit betekenis gaan affekteer?

Waar die logies-empirisme waarnemingsuitsprake as basies beskou en teoretiese terme daar.andaan geïnterpreteer moet word, is die teenoorgestelde uiterste ook moontlik. Teorieë of paradigmas kan so basies word, dat probleme ontstaan oor wat en wanneer iets as 'n teorie geld. Verskillende of alternatiewe teorieë oor die wêreld, natuur of tekste, skep dan hulle 'eie ervaring', of 'empirie'. Keuses tussen teorieë sou gevolglik arbitrêr moet word, want daar is geen gemeenskaplike maatstaf in terme waarvan die een teenoor die ander geëvalueer kan word nie.

Gerhard Doppelt meen dat Kuhn se denke glad nie so iets impliseer of bedoel nie. Kuhn verwys nie soseer na betekenis nie, maar na verskillende vraagstellings, probleme, metodes, visies en interpretasies by verskillende teorieè. Hy meen egter dat daar wel 'n klein mate van spanning in sy denke hieromtrent is.

On the interpretation of Kuhn's relativism to be developed here, it is the incommensurability of scientific problems between rival paradigms and not that of meanings which constitute the most basic premise of the argument. Secondly, so construed Kuhnian incommensurability will turn out to be compatible with a considerable overlap between the language, problems, data and standards of rival paradigms, certainly sufficient overlap to account for the shared content of rational debate which Kuhn as well as his critics find to be a pervasive feature of scientific development.

(Doppelt 1979:39)

Hiervolgens behels Kuhn se denke geen irrasionaliteit of ineenstorting van die kenteoretiese by mededingende paradigmas nie. Dit is veel eerder ' $n$ geval dat daar nie genoegsame oorvleueling bestaan met betrekking tot die probleme en maatstawwe van mededingende paradigmas, om hulle op dieselfde skaal van kriteria te weeg nie. Teenoor vermeende irrasionaliteit by Kuhn stel Doppelt dat 'the balance of reasons or the demands of scientific rationality never unequivocally favor one paradigm (either the old or the new) over its rival; and secondly, that in consequence, contemporary paradigms do not represent progress over what they replace in the sense of progress toward the truth concerning nature' (Doppelt 1979: 39). 
Sowel Shapere as Toulmin meen dat 'n 'middelgrond' tussen die uiterstes (soos reeds geskets) moontlik is en gevind behoort te word. Hulle gee egter nog nie 'n nadere aanduiding van hoe so 'n middelgrond daar sal uitsien nie (Shapere 1981; Toulmin 1972).

Die kwessie van paradigma-geladenheid kom weer ter sprake by die paragraaf oor relativisme.

\section{'n Pre-paradigmatiese fase?}

Daar is volgens Vorster in die Nuwe-Testamentamentiese wetenskap duidelike tekens van 'n paradigma-verandering. Hy dui egter aan dat dit eerder lyk op 'n preparadigmatiese (die nuwe) fase. Dit wil sê die Nuwe-Testamentiese wetenskap het nog nie gekom by een enkele nuwe paradigma, sodat 'n nuwe normale wetenskapsfase kan begin nie. Laasgenoemde noem Kuhn 'mature science'. Volgens hom is die pre-paradigmatiese fase 'n tyd waarin daar wel goeie wetenskaplike werk en wetenskaplikes voorkom, maar dit is 'just less than a science' (Kuhn 1962:13). So behoort byvoorbeeld Galileo Galilei, Kepler, Kopernikus en Tycho Brahe tot die pre-paradigmatiese fase, totdat Newton met sy Principia hulle insluit in sy paradigma.

Vorster se gebruik van 'pre-paradigmaties' is hier egter problematies. Wat hy waarskynlik wil aandui, is die revolusionêre en krisisfase - voordat 'n nuwe paradigma uitkristaliseer. Wanneer daar reeds 'n paradigma bestaan het, kan daar nie weer 'n pre-paradigmatiese fase wees nie. Dit is slegs moontlik in die vroeë fases van 'n wetenskap. Volgens Vorster se lyn van argumentering was die historiese kritiek die reeds bestaande paradigma in die Nuwe-Testamentiese wetenskap.

Ons kan nou vra: Waarom moet daar by die geesteswetenskappe en teologiese wetenskappe juis een enkele paradigma veronderstel word? Daar kan ewe goed geargumenteer word dat daar meer as een paradigma in die veld kan wees, sonder dat dit 'n voorlopige tussenfase moet wees. Die aanvaarding van een enkele paradigma, berus op 'n eg Kuhniaanse siening. Hoekom? Kuhn het hom toegespits op die natuurwetenskappe. Hy dui ook aan dat hy besef dat die situasie by die sosiale wetenskappe baie meer gekompliseerd is. Tewens, daar kan selfs geargumenteer word dat daar in sekere van die naturwetenskappe ook meer as een paradigma teenwoordig kan wees, byvoorbeeld die geologie en geografie. Die bestaan van meer as een paradigma kan selfs beskou word juis as 'mature science'! Moet ons nie vra of die kriteria van wetenskaplikheid by almal geld eerder as die getal van paradigmas nie? Geld sekere algemeen-aanvaarde kriteria van wetenskaplikheid nie vir alle teorieë/paradigmas nie? So sou sekere teorieë meer hieraan beantwoord as ander. Kuhn onderskryf in sy latere fase self sodanige 
kriteria (o a logiese steekhoudendheid, eenvoud, vrugbaarheid, e d m) (Kuhn 1970: 199). Dit sonder dat hy hoef afstand te doen van sy siening dat daar geen rasioneelempiriese grond is in terme waarvan 'n paradigma-verskuiwing plaasvind nie, maar dat dit 'n rewolusionêre gebeure is. Verder kan Kuhn se aanduiding van belangrike kenmerke ten opsigte van paradigmas (perspektief, e $\mathrm{d} \mathrm{m}$ ) vir meer as een paradigma geld. Feyerabend meen dat meer as een teorie nie net moontlik is nie, maar ook wenslik is. Hy praat selfs van 'n proliferasie van teorieë (Feyerabend 1970:212). Hoewel so 'n uiterste nie noodwendig gevolg hoef te word nie, kan daar 'n goeie saak uitgemaak word dat 'n meertal van paradigma sinvol behou kan word, sonder om dan die vereiste aan een enkele paradigma vir die wetenskappe te stel. Die vraag is veel eerder of 'n paradigma, of 'n meertal van paradigmas in dieselfde periode, aan die vereistes van wetenskaplikheid en van paradigmatiese wetenskap self beantwoord. Ek meen dit kan wel. Wanneer daar in die geskiedenis eers 'n paradigma verskyn het, dan kan daar nie weer sommer teruggeval word na 'n preparadigmatiese vlak nie. So 'n moontlikheid is seker nie uitgesluit nie, maar dit sou 'n terugwaartse beweging behels wat gekenmerk word deur sekere eienskappe, waaronder epistemologiese dogmatisme, afwesigheid van vaste metodologie, e a. Dit is twyfelagtig of so iets tans by enige wetenskap, insluitende die teologie, 'n merkbare verskynsel is.

\section{Gesonde kruisbestuiwing tussen verskillende wetenskappe}

Dat paradigma-verskuiwinge plaasvind met verskille in visies, konsepsualisasie, kan goed gerugsteun word in sowel natuur-geestes- en teologiese wetenskappe. Vorster, Van Aarde en Van Arkel toon dit vanuit verskillende hoeke goed aan.

Dat verskillende, selfs heel uiteenlopende wetenskappe, mekaar vrugbaar kan beinvloed en dit ook doen, is vandag iets wat dikwels plaasvind. Waarom sou die teologie as wetenskap hiervan uitgesluit wees? Verwysinge na bepaalde sake in 'n wetenskap, bevat dikwels begrippe en kennis wat ontleen is uit 'n paradigma in 'n ander wetenskap waar dié begrippe en kennis reeds lankal paradigmaties verankerd is. Soms gebeur dit dat daardie paradigma intussen verskuif of deur 'n ander vervang word, maar dat ander wetenskappe wat hierna verwys, nog steeds in terme van tie ou 'vasgestelde' paradigma dink. Dit is dus belangrik dat Van Arkel in sy Theology beyond Newton: $A$ quantum leap, wys op paradigma-verandering in die natuurwetenskap en sy betekenis vir die teologie. Hy verwys veral na die keerpunt wat gekom het met die mikrofisika van Plank, Einstein, Bohr, Heisenberg, Dirac, en andere. Hier het dit geblyk dat die Newtonse paradigma nie probleme kan oplos en ook nie toepasbaar is op die mikrofisiese vlak nie. Eweneens belangrik is die veranderinge vanweë die sisteem-teorie. Laasgenoemde het inderdaad die 'klas- 
sieke' meganistiese perspektiewe as onhoudbaar aangedui, asook die klem laat val op teleologie, organisasie en gehele (holisme).

Dit is opvallend dat teoloë, wanneer hulle praat oor die wetenskap in sy verhouding tot geloof, godsdiens, of teologie, grootliks werk met die ou meganistiese Cartesiaanse model van rekenskap van die wetenskap! Dat dit wel die teoloog se denke oor byvoorbeeld doelmatigheid en selfs eskatologie kan beïnvloed, is moontlik.

Enersyds is kennisname van veranderinge in die natuurwetenskappe nie net as sodanig wenslik en belangrik nie, maar ook goed vir kreatiewe wetenskaplike denke. Andersyds moet daar gewaak word om nie die veranderinge in een wetenskap asook sy invloed (selfs as dit heilsaam is) normatief vir ' $n$ ander te maak nie. So iets is nie net wetenskapsfilosofies problematies nie, maar wetenskapshistories kan dit as onvrugbaar aangetoon word. Die hedendaagse fisika, ondanks die radikale veranderinge, $k a n$ nie sonder meer 'n basis wees waarop alie ander wetenskappe, insluitende die teologie, gemodelleer kan word nie. Dat konsepsualisasies vanuit die nuwe paradigma as meta-teorieë vir die hedendaagse teologiese wetenskappe kan funksioneer (Van Arkel 1988:224), word problematies, aangesien dit dan normatiewe betekenis verkry, of naby daaraan kom.

Vrugbare beïnvloeding vanuit ' $n$ nuwe paradigma in een wetenskap na 'n ander wetenskap, geskied gewoonlik metafories of analogies. Die metaforiese kan soms heel indirek wees, maar wel definitief. Hierby moet gemeld word dat metaforiese oordragte vanuit een wetenskap na 'n ander nie 'n reduksie van die een tot die ander impliseer nie. 'n Reduksionistiese wetenskap sou behels dat wetenskaplike terme wat logies tot een wetenskaplike kategorie behoort, gesubsumeer word in 'n ander kategoric. So byvoorbeeld 'spatial metaphors simply cannot be pressed' (Ryan 1985:105). Die metafoor word dan geforseer tot iets letterliks.

\section{Die probleem van relativisme}

Soos reeds gemeld, het die impak van Kuhn ook die problematiek van relativisme en objektiwiteit meegebring. Van Aarde spreek die probleem aan met betrekking tot die teologie. In die teologiese wetenskappe word 'n veelheid van epistemologiese status aan die Bybel toegeken, sodat dit lei tot ' $n$ veelheid of pluraliteit van eksegetiese metodes. Relativisme sou behels dat evaluasie van iets of iemand in een paradigma, deur iemand vanuit 'n ander paradigma, nie moontlik is nie. As daar geen gemeenskaplike voorraad van nie-relatiewe waarhede sou wees wat as basis kan dien vir kommunikasie nie, dan sou mens kon redeneer dat daar volledige inkommensurabele paradigmas, skemas, ervarings en werklikhede moet wees. Hoe ver sou mens kon gaan om waarheid te relativeer: wat waar is vir Aristoteles is nie 
waar vir Einstein nie. Geld dit nie ook grootliks vir 'n teoloog in die twaalfde en twintigste eeue nie? As ons egter die relatiwiteit van kennis sou deurtrek na 'n relativisme, dan berus die onus op die relativisme om aan te toon hoe paradigmas en teorieë enigsins verband hou met jou data soos waarnemings, handelinge, tekste, dokumente. Hy sal ook moet kan aantoon hoe en waarin 'n nuwe paradigma wel 'n alternatief is. Die relativisme stel dat daar geen konteksvrye of bowe-kulturele norme van rasionaliteit is nie. Daarom sien hy rasioneel aanvaarde en irrasionele aanvaarde kennis nie as twee selfs onderskeie en kwalitatief verskillende klas van dinge nie: 'They do not fall into different natural kinds which make different sorts of appeal to the human mind, or stand in a different relationship to reality or depend for their credibility on different patterns of social organization. Hence the relativist conclusion that they are to be explained in the same way' (Barnes 1988:28). Die relativisme bevraagteker. ule moontlikheid of bestaan van 'n kern wat ondersteun word deur konteks-onafhanklike kriteria van waarheid en rasionaliteit. Kan dit omskryf word en hoe sal sy omtrekke aangedui word - 'But why must we accept that it exists' (Barnes 1988:35)?

Die probleem met dié lyn van argumentering is sy konsekwensies: waaroor gaan die wetenskap dan? Moet dit juis akkuraat omskrywe word? Ons meen nie so nie. Dit is omdat hierdie gemeenskaplike kern geleë is in die leefswêreld (Lebenswelt) van die mens. Ontken jy die leefwêreld trek jy die mat onder jouself uit - selfs die relativisme trek dan sy eie mat onder hom uit. In ons leefwêreld is ons onderskeiding tussen denke, handel, wil, waardeer, nie so duidelik nie - maar reëel. Mary Hesse gebruik nie die term leefwèreld nie, maar kom baie naby daaraan, byvoorbeeld met iets soos die kleur rooi. Wetenskaplike denke en kennis is vir Hesse nooit konteks- of paradigma-vry nie, maar daar is ' $n$ invariansie in ons waarnemingstaal'. Laasgenoemde het 'n stabiliteit met petrekkmg tot hulle funksie wat logies gesproke 'n eienskap is van hoe die wêreld is: 'There are some predicator to which we could always withdraw if challenged in our application of others. There form a unique subset in terms of which "pure descriptions" free from "theoryloading" can be given' (Hesse 1980:82). So kan daar gekwalifiseerd (deur Hesse) onderskei word tussen sekere terme wat meer verskans is as ander, byvoorbeeld 'rooi' meer as 'ultra violet' en 'lood' meer as 'TT-meson'. Daar is sekere terme wat verwys na aspekte van situasies wat meer direk waarneembaar is as ander, terwyl daar weer sekere begrippe is in terme waarvan ander geanker is aan die empiriese gegewens.

Ander wetenskappe sou ander waarneembare gegewens of parallelle kan konstateer, soos dokumente, inskripsies, en andere. Met dié dat paradigmas verskuif, sou so iets soos 'ultra violet' 'n ander inhoud of betekenis kon kry, of selfs vervang 
word deur 'n ander term of terme, maar nie sommer 'rooi' nie. Vergelykbaar stel Brown (1987:197): 'For these purposes, it is sufficient that the items we observe are ontologically independent of the hypothesis being tested'. Juis die verwysing na een of ander item in die fisiese wêreld, onderskei waarneming van hallusinasie, vrye assosiasie en ander geestelike verskynsels.

Scientific observation is always aimed at making sense of information that exists independently of our beliefs, and that can surprise us no matter what we already believe.... The physical world does not dictate the results of an observation, but it does constrain those results and the fact that the physical world exists independently of our beliefs is sufficient to account for the way observation can upset any body of beliefs.

(Brown 1987:197, 198)

Waarneming sluit nie feilbaarheid uit nie. Daarom sien Brown objektiwiteit nie as 'n prestasie nie, maar 'n proses.

Belangrik is dat wanneer Brown praat van 'die wêreld wat onafhanklik bestaan van ons kennis, dat hierdie onafhanklikheid nie 'n an sich wereld word nie. Te onderskeie van die klassieke Cartesiaanse realisme, steun Brown 'n nuwe vorm van realisme - maar so ook Kuhn! Kuhn beskou egter die uitdrukking 'onafhanklik' hier as verkeerd. Sy realisme blyk daarin dat hy beweer dat die normale en paradigmatiese wetenskap voortdurend poog om paradigmas/teorieë nader aan die wêreld te bring. Brown gebruik wel die uitdrukking onafhanklik, maar aanvaar grootliks die begrip paradigma soos by Kuhn. In plaas van 'n onafhanklike objek, praat Husserl van die noematiese.

Hierbenewens hef die relativisme die demarkasie van wetenskap, nie-wetenskap en onwetenskap op. Toegegee dat nie-wetenskaplik (te onderskei van onwetenskaplik) ook rasionaliteit behels, ook die 'aanbied van redes vir...' sou insluit. Rasionaliteit is nie afgegrens slegs tot teoretiese rasionaliteit nie. Dit hef egter nie die eie aard van teoretiese rasionaliteit op nie. Of die een gestalte van rasionaliteit beter is as die ander, is nie ter sake nie.

Ons het reeds laat blyk dat Kuhn se paradigma-denke nie hierdie relativisme of selfs die ophef van teoretiese rasionaliteit impliseer nie. Wel is dit so dat niewetenskaplike faktore inspeel by die ontstaan van die paradigma en in die konteks van ontdekking. 
Wanneer ons dus ' $n$ 'kern van gemeenskaplike voorraad' by die paradigmas in 'n bepaalde gebied sou aanvaar, dan aanvaar ons wel 'n relatiwiteit (relatief tot 'n paradigma), maar nie 'n relativisme nie. Relativisme sou 'n absolutering van gesigspunte beteken. Van Aarde stel tereg in sy Historical Criticism and holism: Heading towards a new paradigm?: 'Absolutising viewpoints cannot mean advance.... Advance can also exist in the toleration for plurality as such, the preservation of plurality and the reflection on plurality's pragmatic meaning' (Van Aarde 1988:5152).

Van Aarde neem aan dat holisme in die wetenskap relativisme en onverdraagsaamheid sou impliseer. Dit is waarskynlik omdat hy grootliks met Capra se opvatting van holisme werk. 'n Onverdraagsaamheid sou moontlik wees indien 'n alomvattende, universele holisme een of ander geslote sisteemdenke sou behels. So iets is egter vandag uitsonderlik. Selfs by Capra is dit hoogs onwaarskynlik. ' $n$ Relativisme is meesal skepties of indifferent ten opsigte van die waarheid en juis daarom nie onverdraagsaam nie.

Verder is daar verskillende soorte en vlakke van holismes. So byvoorbeeld is daar ontologiese of metafisiese en epistemologiese holismes. 'n Paradigma sou ook as 'n epistemologiese holisme beskou kon word: Dis 'n eenheid-stigtende perspektief. Dit plaas en sien objekte, areas, probleme, metodoloige binne 'n geheelbeeld.

\section{SLOT}

Relativisme kan moeilik gehandhaaf word. Relatiwiteit egter wel. Objektiwiteit sluit nie die relatiwiteit van wetenskaplike kennis uit nie. Hierdie relatiwiteit dui op die paradigma/teorie geladenheid van ons kennis. Enersyds is bruta facta buite die kwessie. Andersyds is daar vir alle paradigmas 'n gemeenskaplike verwysing van sekerheid: Wetenskaplike kennis is nie solipsisties nie. By alle wetenskaplike arbeid is daar die nie-ego (epistemologies gesproke!) in die kenrelasie. In ons paradigmatiese kenning van ons wêreld, is daar iets wat ons (kenner) nie self gemaak of geskep het nie. Dit is hoekom 'n paradigmatiese konteks of teorie-geladenheid onderskei kan word van 'n arbitrêre verdraaing van die gekende. Dis hoekom wetenskaplikes vanuit verskillende, en selfs teenoorstaande paradigmas, sekere aangeleenthede op dieselfde wyse as beperkend ervaar. Hesse noem dit 'constraints'. Meer as een interpretasie is dikwels moontlik - maar nie enigiets is moontlik nie! 


\section{Literatuurverwysings}

Barnes, B \& Bloor, D 1988. Relativism, rationalism and the sociology of knowledge, in Hollis, M \& Lykes, S (eds), Rationality and relativism. Oxford: Blackwell.

Brown, H I 1987. Obsenvation and objectivity. Oxford: Oxford University Press.

Doppelt, G 1979. Kuhn's epistemological relativism: An interpretation and defense. Inquiry 21, 33-86.

Feyerabend, P K 1970. Consolations for the specialist, in Lakatos, I \& Musgrave, A (eds), Criticism and the growth of knowledge. Cambridge: Cambridge University Press.

Hanson, N R 1958. Pattern of discovery. Cambridge: Cambridge University Press.

Hesse, M 1980. Revolutions and reconstruction in the philosophy of science. Brighton: The Harvester Press.

Kuhn, T S 1962. Structure of scientific revolutions. Chicago: University of Chicago Press.

Kuhn, T S 1970. Structure of scientific revolutions. Chicago: University of Chicago Press.

Mouton, J, Van Aarde, A G \& Vorster, W S (eds) 1988. Paradigms and progress in theology. Pretoria: HSRC. (HSRC Studies in Research Methodology.)

Ryan, A 1985. The philosophy of the social sciences. London: MacMillan.

Shapere, D 1981. Meaning and scientific change, in Hacking, I (ed), Scientific revolutions. Oxford: Oxford University Press.

Toulmin, S 1972. Human understanding, vol 1. Oxford: Clarendon.

Van Aarde, AG 1988. Historical criticism and holism: Heading toward a new paradigm?, in Mouton, Van Aarde \& Vorster 1988:49-64.

Van Arkel, J G de J 1988. Theology beyond Newton: A quantum leap, in Mouton, Van Aarde \& Vorster 1988:223-238.

Vorster, W S 1988. Towards a post-critical paradigm: Progress in New Testament Scholarship?, in Mouton, Van Aarde \& Vorster 1988:31-48. 